\title{
PREVALENCE AND POPULATION AT RISK FOR NOISE INDUCED HEARING LOSS (NIHL) IN ADOLESCENT STUDENTS
}

\author{
Yusni Yusni ${ }^{1}$, Ikbal Ikbal' ${ }^{2}$, Firdalena Meutia ${ }^{3}$ \\ ${ }^{1}$ Department of Physiology, Faculty of Medicine, Universitas Syiah Kuala, Darussalam, Banda Aceh, Indonesia \\ ${ }^{2}$ Department of Otorhinolaryngology, dr. Zainoel Abidin Hospital, Banda Aceh/Faculty of Medicine, Universitas \\ Syiah Kuala, Darussalam, Banda Aceh, Indonesia \\ ${ }^{3}$ Department of Ophthalmology, dr. Zainoel Abidin Hospital, Banda Aceh, Faculty of Medicine, Universitas Syiah \\ Kuala, Darussalam, Banda Aceh, Indonesia
}

\section{ABSTRACT}

Noise-Induced Hearing Loss (NIHL) is a global health problem, often underestimated, and leads to permanent hearing loss. The prevalence of NIHL in adolescents has increased in line with the increasing use of cell phones. This study aimed to determine the prevalence of NIHL and analyze the population at risk (age, gender, and school) in adolescent students. The study design was a cross-sectional study. A total of 510 students consisting of female, $n=288$ and male, $n=222 ; j u n i o r ~ h i g h$ school, $n=203$ and senior high school, $n=307$ were used as research subjects. This study was conducted on August-October 2015 at Darul Ihsan School, Banda Aceh, Indonesia. An audiometry examination was performed to determine the diagnosis of NIHL. Data analysis was using descriptive analysis and independent sample t-test( $p<0.05)$. The results of this study were the prevalence of NIHL in adolescents aged 11-20 years was 18.88\%. The highest percentage of NIHL was at the age of 15 years $(34.57 \%)$. The number of NIHL was significantly higher $\left(p=0.000^{*}\right)$ in males $(24.32 \%)$ compared to females $(9.37 \%)$. The prevalence of NIHL was significantly higher $(p=0.00 *)$ in senior high school children $(26.11 \%)$ compared to that in junior high school children (9.12\%). In conclusion, the highest prevalence of NIHL was at the age of 15 years. NIHL was more common in male than in female students. NIHL was higher in high school students compared to junior high school students. The NIHL was related to age, gender, and school level.

Keywords: Prevalence; risk factor; noise induced hearing loss; adolescent; illness

\section{ABSTRAK}

Noise Induced Hearing Loss (NIHL) adalah masalah kesehatan global yang sering kali disepelekan dan mengakibatkan ketulian permanen. Angka prevalensi NIHL pada remaja mengalami peningkatan sejalan dengan meningkatnya penggunaan telepon seluler. Penelitian ini bertujuan mengetahui prevalensi NIHL dan menganalisis populasi risikonya (usia, jenis kelamin, dan sekolah) pada remaja sekolah. Desain penelitian ini adalah cross-sectional study. Sebanyak 510 siswa/siswi: wanita, $n=288$ dan pria, $n=222 ;$ SMP, $n=203$ dan SMA, $n=307$ digunakan sebagai subjek penelitian. Penelitian dilaksanakan pada Agustus hingga Oktober 2015 di Sekolah Darul Ihsan, Banda Aceh, Indonesia. Pemeriksaan audiometri dilakukan untuk menentukan diagnosis NIHL. Analisis data menggunakan analisis deskriptif dan independent sample t-test $(p<0,05)$. Hasilnya adalah prevalensi NIHL pada remaja usia 11-20 tahun sebanyak 15,88\%. Persentase NIHL yang terbanyak adalah pada usia 15 tahun (34,57\%). Jumlah penderita NIHL lebih banyak secara bermakna $(p=0,000 *)$ pada pria $(24,32 \%)$ dibandingkan dengan wanita (9,37\%). Prevalensi NIHL secara bermakna lebih banyak $(p=0,00 *)$ pada anak SMA $(26,11 \%)$ dibandingkan dengan anak SMP (9,12\%). Kesimpulan: prevalensi NIHL tertinggi adalah pada usia 15 tahun. NIHL lebih banyak pada pria dibandingkan dengan wanita. NIHL pada anak SMA dengan NIHL lebih banyak dibandingkan anak SMP. NIHL berhubungan dengan usia, jenis kelamin dan tingkat sekolah.

Kata kunci: Prevalensi; faktor risiko; noise induced hearing loss; remaja; illness

Correspondence: Yusni, Department of Physiology, Faculty of Medicine, Universitas Syiah Kuala, Darussalam, Banda Aceh, Indonesia 23111. Email: yusni@unsyiah.ac.id

pISSN:2355-8393 • eISSN: 2599-056x • doi: 10.20473/fmi.v57i3.20391

- Fol Med Indones. 2021;57:214-219 • Submitted 30 Jun $2020 \bullet$ Received 03 Feb $2021 \bullet$ Accepted 11 Aug 2021

- Open access under CC-BY-NC-SA license • Available at https://e-journal.unair.ac.id/FMI/ 


\section{INTRODUCTION}

Hearing loss is a public health problem today that does not only occur in adults, but also in adolescents (Gilles et al 2013). Lifestyle changes among adolescents in millennial era today have an impact on increasing use of electronic media such as cellphones, iPad, tablets, computers/laptops, online games, and portable music devices (Baranovskyj et al 2016). The main cause of hearing loss is excessive noise exposure (SliwinskaKowalska \& Zaborowski 2017).

In addition, the habit of using earphones for more than 2 hours will have an impact on hearing loss that may lead to permanent deafness. A study by Cerquone et al (2006) showed that $78 \%$ of adolescents used earphones connected to music players from cellphones, $12 \%$ from MP3 players, and 35\% from laptops. The use of earphones with loud noise (intensity> $85 \mathrm{~dB}$ ) and long duration (around 1-3 hours or more) every day is one of the risk factors for hearing loss due to noise, called Noise Induced Hearing Loss (NIHL) (Azizi 2016, Gunny et al 2018, Mazlan et al 2018). As many as 36 million people in America experience hearing loss and around 1 in 3 is NIHL. Data from 2006 states that 1 in 5 adolescents aged 12-19 years in America experience NIHL.

NIHL is defined as a condition of hearing loss or sensorineural deafness induced due to continuous high noise exposure (> $80 \mathrm{~dB}$ ) in a long term (Jumali et al 2013, Ding et al 2019). NIHL is the most common type of sensorineural deafness in adolescents (Baranovskyj et al 2016). NIHL is a health problem in school-age children that deserves attention because it affects daily learning activities and achievement at school (Absalan et al 2013). Generally, NIHL occurs gradually and progressively so that the sufferers are not aware (Azizi 2016).

Exposure to excessive noise results in damage to sensory cells in the inner ear or the cochlea, especially to outer hair cells (Sliwinska-Kowalska \& Zaborowski 2017). NIHL is irreversible or, in other words, its hearing function cannot be reversed to its original state (Azizi 2016, Baranovskyj et al 2016). Therefore, early preventive measures are the main priority to reduce the number of NIHL incidents and reduce the risk of permanent deafness. Prevention from an early age can be done by screening school-age children from an early age. Therefore, it is important to conduct research on the prevalence of NIHL in school-age children, especially adolescents in the city of Banda Aceh, Indonesia.
The World Health Organization (WHO) estimates that as many as 360 million people, or $5 \%$ of the population worldwide, in 2017 suffer from deafness, and 1.1 million of them were at the age of 12-35 years (Sliwinska-Kowalska \& Zaborowski 2017, Ding et al 2019). Meanwhile, the World Health Organization in 2015 indicated the prevalence of deafness in adolescents aged 12-19 years is $3.5 \%-5.3 \%$. The prevalence of hearing loss in grade 11 children in Pennsylvania is $19 \%$ of a total of 282 (Sekhar et al 2014). The prevalence of hearing loss in adolescents aged 12-19 years in America has increased significantly from year to year. In 1988-1994, the prevalence rate was around $14.9 \%$, but in 2005-2006 it increased to $19.5 \%$ (Shargorodsky et al 2010).

Based on National Adolescent and Young Adult Health Center in 2014, one in five adolescents aged 12-19 years in the United States experience deafness. Besides, World Health Organization data in 2018 showed the increased prevalence of deafness has an impact on increasing annual costs of more than 750 billion dollars. WHO data from 1998 reflects that the prevalence of deafness in Indonesia ranks 4th in Southeast Asia, with a percentage of around $4.6 \%$ and Sri Lanka has the highest prevalence at $8.8 \%$, Myanmar $8.4 \%$, and India $6.3 \%$ or affecting 63 million people (Singh 2015). However, 2014 the prevalence of NIHL in Indonesia was the highest in Asia, reaching 36 million people or around $16.8 \%$ of the total population (Septiana \& Widowati 2017).

The prevalence of NIHL in school adolescents aged 1120 years in Banda Aceh is unknown. Therefore, this study was conducted to analyze the prevalence of NIHL in junior and senior high school adolescents in Banda Aceh, Indonesia. Data from the results of this study were expected to be useful for early preventive measures to prevent the increased permanent deafness in adolescents.

\section{MATERIALS AND METHODS}

The materials in this study were examination forms and audiometry to examine hearing function (to detect NIHL). This study was an observational analytic study with cross-sectional design. This study aimed to compare the number of NIHL incidents between junior and senior high school students. Comparison of the incidents was also correlated with age and gender. The study sites were Darul Ihsan Junior High School and High School in Siem, Aceh Besar, Banda Aceh, Indonesia. This study was conducted on August to October 2015. Darul Ihsan School is an Islamic school with boarding school concept. 
The population was all students of Darul Ihsan. The sample of the study was Darul Ihsan Junior and Senior High School students with some classifications, namely male and female students, adolescents between 11-20 years old, in healthy condition, willing to be the subjects in this study, and willing to undergo examinations. This study used a total population sampling method, meaning that all populations were subject to research. The total number of subjects was 510 students, with female $\mathrm{n}=$ 288 and male $\mathrm{n}=222$, while students attending Junior High School were $n=203$ and Senior High School were $\mathrm{n}=307$.

The results of the examination were in the form of characteristic data, such as age and gender. Hearing function examination data were obtained using pure tone audiograms. Audiometry examination was performed to determine the diagnosis of NIHL. Audiometric examination and analysis were performed by specialists in ear, nose, throat, head and neck surgery. Data analysis was carried out using descriptive analysis (frequency and percentage) and independent sample t-test $(\mathrm{p}<0.05)$ to analyze differences in NIHL prevalence based on age, gender, and school type.

This study was carried out after obtaining permission from the Research Ethics Committee of the Faculty of Medicine, Universitas Syiah Kuala, Banda Aceh, Indonesia, and the permission from the principals of each school. Before the examination, all students received an explanation of the objectives, benefits, and risks derived from this study. Furthermore, all subjects who were willing to volunteer were given an informed consent sheet to be signed.

\section{RESULTS}

The examination of the subjects yielded data on the subjects' characteristics (age and gender) and data from audiogram analysis to determine the diagnosis of NIHL. Characteristics of the subjects showed that from a total of 510 subjects, the number of Junior High School students was higher than that of Senior High School students. Likewise, related to gender, there were more female than male students, both in Junior and Senior High School.

Table 1. Distribution of adolescents by school and gender

\begin{tabular}{lccccc}
\hline \multirow{2}{*}{ School } & \multicolumn{4}{c}{ Gender } & \multirow{2}{*}{ Total } \\
\cline { 2 - 5 } & \multicolumn{2}{c}{ Female } & \multicolumn{2}{c}{ Male } & \\
\cline { 2 - 5 } & $\mathrm{n}$ & $\%$ & $\mathrm{n}$ & $\%$ & \\
\hline Junior High & 169 & 55.05 & 138 & 44.95 & 307 \\
Senior High & 119 & 58.62 & 84 & 41.38 & 203 \\
Total & 288 & & 222 & & 510 \\
\hline
\end{tabular}

The characteristics of subjects by age can be seen in Table 1. Most of the samples were 13 years old (114 students), and the least was 19 years old (1 student). The minimum age of the subject was 11 years (Junior High School) and the maximum age was 20 years (Senior High School). The mean age of the subjects was 12.81 years among Junior High School students and 15.50 years in Senior High School students.

Audiometry examination in Table 2 showed that the highest number of junior and senior high school students diagnosed with NIHL was 15 years of age (34.57\% of total NIHL sufferers). The percentage of junior and senior high school children (aged between 11-20 years) who experienced NIHL was $15.88 \%$ of the total subjects.

Table 2. Prevalence of NIHL by age

\begin{tabular}{|c|c|c|c|c|c|}
\hline \multirow{3}{*}{$\begin{array}{c}\text { Age } \\
\text { (years) }\end{array}$} & \multicolumn{4}{|c|}{ Diagnosis } & \multirow{3}{*}{ Total } \\
\hline & \multicolumn{2}{|c|}{ Normal } & \multicolumn{2}{|c|}{ NIHL } & \\
\hline & $\mathrm{n}$ & $\%$ & $\mathrm{n}$ & $\%$ & \\
\hline 11 & 14 & 3.26 & 0 & 0 & 14 \\
\hline 12 & 103 & 24.01 & 10 & 12.35 & 113 \\
\hline 13 & 99 & 23.08 & 15 & 18.52 & 114 \\
\hline 14 & 66 & 15.38 & 5 & 6.17 & 71 \\
\hline 15 & 85 & 19.81 & 28 & 34.57 & 113 \\
\hline 16 & 44 & 10.26 & 15 & 18.52 & 59 \\
\hline 17 & 15 & 3.50 & 4 & 4.94 & 19 \\
\hline 18 & 2 & 0.47 & 2 & 2.47 & 4 \\
\hline 19 & 1 & 0.23 & 0 & 0 & 1 \\
\hline 20 & 0 & 0 & 2 & 2.47 & 2 \\
\hline Total & 429 & 100 & 81 & 100 & 510 \\
\hline
\end{tabular}

The Table 3 described the analysis of audiometry examination by gender. It showed that NIHL was found in significantly $(\mathrm{p}=0.000)$ higher number $(24.32 \%)$ in male students compared to female students $(9.37 \%)$. The number of students who experienced NIHL in both ears (left and right ear) in male and female students was higher than students with NIHL in one ear (left or right ear). NIHL in children aged 11-20 years mostly affected both ears (around 76.54\%), while those who experienced NIHL in the right ear was around $17.28 \%$ and the left ear was $6.17 \%$.

Table 3. Prevalence of NIHL by gender

\begin{tabular}{|c|c|c|c|c|c|c|}
\hline \multirow{3}{*}{ Gender } & \multicolumn{4}{|c|}{ Diagnosis } & \multirow{3}{*}{ Total } & \multirow{3}{*}{ Significance } \\
\hline & \multirow{2}{*}{ Normal } & \multicolumn{3}{|c|}{ NIHL } & & \\
\hline & & $\mathrm{AD}$ & AS & $\mathrm{AD}+\mathrm{AS}$ & & \\
\hline Female & 261 & 6 & 5 & 16 & 288 & \\
\hline Male & 168 & 8 & 0 & 46 & 222 & $0.000^{*}$ \\
\hline Total & 429 & 14 & 5 & 62 & 510 & \\
\hline
\end{tabular}


*Significant at 5\% error ( $<<0.05)$; $\mathrm{AD}=$ auricular dextra/right ear; AS = auricular sinistra/left ear

The comparison of NIHL students by type of school in Table 4 showed that the number of NIHL students was significantly higher $(p=0.000)$ in Senior High School $(n=53)$ compared to Junior High School $(n=28)$. The percentage of NIHL students in Junior High School was 9.12\%, while in Senior High School was almost 3 times higher $(26.11 \%)$.

Table 4. Prevalence of NIHL by school

\begin{tabular}{lc|ccccc}
\hline \multirow{2}{*}{$\begin{array}{l}\text { Type } \\
\text { of }\end{array}$} & \multicolumn{4}{|c}{ Diagnosis } & & \\
\cline { 2 - 5 } School & & \multicolumn{3}{c}{ NIHL } & Significance \\
\cline { 2 - 5 } & Normal & AD & AS & AD + AS & & \\
\hline Junior & 279 & 8 & 3 & 17 & 307 & $0.000 *$ \\
\hline
\end{tabular}

\begin{tabular}{lccccc}
\hline High & & & & & \\
Senior & 150 & 6 & 2 & 45 & 203 \\
High & 429 & 14 & 5 & 62 & 510 \\
Total & 4 & \\
\hline
\end{tabular}

Table 5 showed that the number of students with NIHL in Senior High School was significantly higher $(\mathrm{p}=$ 0,000 ) in male students compared to female. Similarly, in Junior High School, the number of students with NIHL was higher in male than in female although it was not statistically significant $(\mathrm{p}=0.06)$.

Table 5. Comparison of NIHL prevalence by school and gender

\begin{tabular}{|c|c|c|c|c|c|c|c|}
\hline \multirow{3}{*}{ School } & \multirow{3}{*}{ Gender } & \multicolumn{4}{|c|}{ Diagnosis } & \multirow{3}{*}{ Total } & \multirow{3}{*}{ Significance } \\
\hline & & & \multicolumn{3}{|c|}{ NIHL } & & \\
\hline & & Normal & $\mathrm{AD}$ & $\mathrm{AS}$ & $\mathrm{AD}+\mathrm{AS}$ & & \\
\hline \multirow{3}{*}{$\begin{array}{l}\text { Junior High } \\
\text { School }\end{array}$} & Female & 157 & 4 & 3 & 5 & 169 & \multirow{3}{*}{0.06} \\
\hline & Male & 122 & 4 & 0 & 12 & 138 & \\
\hline & Total & 279 & 8 & 3 & 17 & 307 & \\
\hline \multirow{3}{*}{$\begin{array}{l}\text { Senior High } \\
\text { School }\end{array}$} & Female & 104 & 2 & 2 & 11 & 119 & \multirow{3}{*}{$0.00^{*}$} \\
\hline & Male & 46 & 4 & 0 & 34 & 84 & \\
\hline & Total & 150 & 8 & 2 & 45 & 203 & \\
\hline
\end{tabular}

\section{DISCUSSION}

Noise-induced hearing loss is a serious health problem as it has caused hearing loss in $21 \%$ of worldwide population (Lie et al 2016). Hearing loss is the forth cause of disability in the United States (Ropper et al 2017), and is a major disability problem in the world (Masterson et al 2016). NIHL is a frequently unrecognized problem, especially in non-workplace environments, such as children environment (Martin et al 2006). NIHL is more common among adolescents (Shargorodsky et al 2010, Sekhar et al 2014).

Exposure to noise in excess of $80 \mathrm{~dB}$ in the long term has increased the risk of deafness ( $\mathrm{Ijaz}$ et al 2014, Gunny et al 2018). In addition, age, sex, and workplace are factors that influence the prevalence of NIHL (Strauss et al 2012, Musiba 2015, Sam et al 2017). NIHL is more common in adults compared to children (Lie et al 2016, Sułkowski et al 2017). Based on the National Adolescent and Young Adult Health Information Center in 2014, the increased use of cellular technology such as cell phones and portable music players has an impact on hearing loss in adolescents.
In this study, we found that the prevalence of NIHL in school adolescents aged 11-20 years was $18.88 \%$. This prevalence rate was three times higher than WHO data in 2015. A study on workers in Tanzania has found that as many as $58.5 \%$ of the total 265 workers experienced NIHL and the prevalence in men $(67.7 \%)$ was higher than in women (Abraham et al 2019). A study in America stated that one of four $(24 \%)$ of adults experienced hearing loss due to noise and its prevalence was more in men (Carroll et al 2017). Long-term exposure to noise causes progressive apoptosis in hair cells and also results in the degeneration of spiral ganglion neurons which resulted in decreased hearing threshold which ultimately resulted in hearing loss or permanent deafness (Ding et al 2019).

Noise-induced hearing loss is more common in developing countries and decreases in industrialized countries (Jamal et al 2016, Lie et al 2016). The prevalence of hearing loss is $91 \%$ in adults and $9 \%$ in children (Taneja 2016). Hearing loss results in hearing disability (Taneja 2016). The prevalence of hearing disability in Southeast Asia was 2.4\%; in adults aged $<65$ years was $9.5 \%$ and those aged $>65$ years was $48 \%$ (Taneja 2016). The main cause of deafness was due to 
noise and as much as $15 \%$ due to noise at work or cell phone use (Taneja 2016).

Hearing loss is more common in men than women (Le et al 2017). The prevalence of NIHL in children and adolescents is increasing and impact on academic achievement (Martin et al 2006, Ehlert 2016). A study conducted in Iran on 1,500 Elementary School students showed that the prevalence of conductive hearing loss in boys was $8.8 \%$ and $7.1 \%$ in girls; this result was similar to sensorineural hearing loss of $1 \%$ in men and $0.7 \%$ in women (Absalan et al 2013). The results of the previous study were similar to our results that the prevalence of NIHL in male adolescents was higher than that in female. Besides, a study on 109 textile factory workers in Bandung, Indonesia, also found that the prevalence of hearing loss in men was higher than in women (Dewi \& Agustian 2012).

More importantly, noise-induced hearing loss is a public health problem that is often underestimated. However, a study indicated the prevalence of NIHL continued to increase (Nyarubeli et al 2019). The prevalence of NIHL increased dramatically from 120 million people in 1995 to 466 million people in 2018 (Nyarubeli et al 2019). NIHL is a complex hearing loss disease that is caused by interactions between genetic and environmental factors, but generally occurs due to biological damage as a cause of noise (Le et al 2017). NIHL is progressive and irreversible ( $\mathrm{Li}$ et al 2020). Many factors can cause NIHL, such as noise, not using ear protectors, organic solvents, alcohol, high temperature, genes and comorbidity ( $\mathrm{Li}$ et al 2020). Hearing loss can occur due to damage to the inner ear, particularly in the part of the cochlea (Bazard et al 2021).

\section{CONCLUSION}

The prevalence of NIHL in school adolescents aged 1120 years was $15.88 \%$. The percentage was more in men $(24.32 \%)$ compared to women $(9.37 \%)$. The highest percentage of children with NIHL was 15 years old, consisting of $34.57 \%$ of all children. Senior High School children suffering from NIHL was higher compared to Junior High School children. Somehow, NIHL is related to age, gender and school level. On the other hand, this study remained that not all risk factors were examined in this study. We merely focused on three risk factors for NIHL, namely age, gender and level of school. Therefore, this study can followed-up by analyzing other risk factors, such as the type of work/workplace, and the use of earphones or similar devices.

\section{REFERENCES}

Abraham Z, Massawe E, Ntunaguzi D, et al (2019). Prevalence of noise-induced hearing loss among textile industry workers in Dar es Salaam, Tanzania. Annals of Global Health 85, 1-6.

Absalan A, Pirasteh I, Khavidaki GAD, et al (2013). A prevalence study of hearing loss among primary school children in the South East of Iran. International Journal of Otolaryngology 2013, 1-4.

Gunny AAN, Mydin RH, Abdullah S (2018). NoiseInduced hearing loss: Engineering control at industry and clinical audiology approach at hospital level. IOP Conf. Series: Materials Science and Engineering, 429, $1-6$.

Jumali J, Sumadi S, Andriani S, et al (2013). Prevalensi dan faktor risiko tuli akibat bising pada operator mesin kapal feri. Kesmas, Jurnal Kesehatan Masyarakat Nasional 7, 545-550.

Azizi MH (2016). Occupational noise-induced hearing loss. International Journal of Occupational and Environmental Medicine 1, 116-123.

Baranovskyj S, Alcaràs $\mathrm{P}$, Lacerda A (2016). Educational action focused on the prevention of hearing loss due to high sound pressure levels and on tinnitus-An experience report. Otolaryngology Open Access Journal 1, 97-102.

Carroll YI, Eichwald J, Scinicariello F, et al (2017). Vital signs: Noise-induced hearing loss among adultsUnited States 2011-2012. Morbidity and Mortality Weekly Report 66, 139-144.

Cerquone J, Wittman R, Scott K (2006). Survey of adults in Mexico and Puerto Rico about the use of personal electronic devices with head phones. Zogby International, United States of America.

Dewi YA, Agustian RA (2012). Skrining gangguan dengar pada pekerja salah satu pabrik tekstil di Bandung. MKB 44, 96-100.

Ding T, Yan A, Liu K (2019). What is noise-induced hearing loss?. British Journal of Hospital Medicine 80, 525-529.

Ehlert K (2016). Perceptions of public primary school teachers regarding noise-induced hearing loss in South Africa. South African Journal of Communication Disorders 64, 1-12.

Gilles A, Hal GV, Ridder DD, et al (2013). Epidemiology of noise-induced tinnitus and the attitudes and beliefs towards noise and hearing protection in adolescents. PLOS ONE 8, 4-11.

Ijaz S, Verbeek J, Toppila E, et al (2014). A systematic review of predictors of noise induced hearing loss, Finnish Institute of Occupational Health 2014, 1-61.

Jamal A, Tanoli Q, Putus T, et al (2016). Noise induced hearing loss and its determinants in workers of an Automobile manufacturing unit in Karachi, Pakistan. Madridge Journal of Otorhinolaryngology 1, 1-11. 
Le TN, Straatman LV, Lea J, et al (2017). Current insights in noise-induced hearing loss: a literature review of the underlying mechanism, pathophysiology, asymmetry, and management options. Journal of Otolaryngology-Head and Neck Surgery 46, 1-15.

Li X, Rong X, Wang Z, et al (2020). Association between smoking and noise-induced hearing loss: A meta-analysis of observational studies. International Journal of Environmental Research and Public Health 17, 1-14.

Lie A, Skogstad M, Johannessen HA, et al (2016). Occupational noise exposure and hearing: a systematic review. International Archives of Occupational and Environmental Health. Springer Berlin Heidelberg 89, 351-372.

Martin WH, Sobel J, Griest SE, et al (2006). Noise induced hearing loss in children: Preventing the silent epidemic. Journal of Otology 1, 11-21.

Mazlan AN, Yahya K, Haron Z, et al (2018). Characteristic of noise-induced hearing loss among workers in construction industries. E3S Web of Conferences 34, 1-9.

Musiba Z (2015). The prevalence of noise-induced hearing loss among Tanzanian miners. Occupational Medicine 65, 386-390.

Nyarubeli IP, Tungu AM, Moen BE, et al (2019). Prevalence of noise-induced hearing loss among Tanzanian iron and steel workers: A cross-sectional study. Int. J. Environ. Res. Public Health 16, 1-13.

Ropper AH, Cunningham LL, Tucci DL (2017). Hearing loss in adults. The New England Journal of Medicine 377, 2465-2473.

Sam W, Anita A, Hayati K, et al (2017). Prevalence of hearing loss and hearing impairment among small and medium enterprise workers in Selangor, Malaysia. Sains Malaysiana 46, 267-274.
Sekhar DL, Zalewski TR, Ghossaini SN, et al (2014). Pilot study of a high-frequency school-based hearing screen to detect adolescent hearing loss. J Med Screen 21, 18-23.

Septiana NR, Widowati E (2017). Gangguan pendengaran akibat bising. HIGEIA: Journal of Public Health Research and Developmental 1, 73-82.

Shargorodsky J, Curhan SG, Curhan GC, et al (2010). Change in prevalence of hearing loss in US adolescents. JAMA 304, 772-778.

Singh V (2015). Hearing in India: All aspects. Otolaryngology Online Journal 5, 1-31.

Sliwinska-Kowalska M, Zaborowski K (2017). WHO environmental noise guidelines for the European region: A systematic review on environmental noise and permanent hearing loss and tinnitus. International Journal of Environmental Research and Public Health 14, 1-19.

Strauss S, Becker SP, Eloff HZ (2012). Prevalence and degree of noise-induced hearing loss in South African gold miners. Occupational Health Southern Africa 18, 20-25.

Sułkowski W, Owczarek K, Olszewski J (2017). Contemporary noise-induced hearing loss (NIHL) prevention. Otolaryngol Pol 71, 1-5.

Taneja MK (2016). Noise-induced hearing loss. Indian Journal of Otology 20, 151-154.

Bazard P, Frisina RD, Acosta AA, et al (2021). Roles of key ion channels and transport proteins in age-related hearing loss. International Journal of Molecular Sciences 22, 1-27.

Masterson EA, Bushnell PT, Themann CL, et al (2016). Hearing impairment among noise-exposed workers United States, 2003-2012. Morbidity and Mortality Weekly Report 65, 389-394. 